\title{
POPULARIZATION OF CASTOR (PCH 111) AMONG THE SMALL FARMERS OF MAHABUBNAGAR DISTRICT OF TELANGANA THROUGH FRONTLINE DEMONSTRATION
}

\author{
M. SATYANARAYANA ${ }^{1}$, K. SARITHA $^{2}$, P. SPANDANABHATT $^{3} \&$ G. SAMUEL $^{4}$

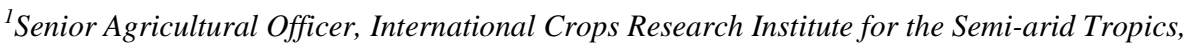 \\ Patancheru, Telanagana, India \\ ${ }^{2,3,4}$ Krishi Vigyan Kendra, Palem, Mahabub Nagar District, Telangana, India
}

\begin{abstract}
A total of 20 fields of farmers residing in Mahabubnagar district of south zone of Telangana state were selected for the experimental study. The field studies were conducted by the Krishi Vigyan Kendra, Palem to evaluate the production and economic benefits of castor (PCH 111) production by applying scientific technology. The crop cultivated during the kharif season of 2012-13 and 2013-14 (two consecutive years) was selected for testing and analyses. The fields of the farmers were located in the village of Chenchugudem, Gudibanda and Chakalpalyy. Extension gap, technology gap and technology index were calculated. On the basis of these technologies, improved production in the hybrid PCH 111 ranged between 36 and 54 q/ha for 2012 (mean yield 44 q/ha) and between 39 and 49 q/ha for 2013 (44 q/ha).However, for the local hybrid, the production ranged between 35 and 40 q/ha. Frontline demonstrations (FLDs) can promote new crops and technologies and improve their popularity. Such improvements in crop technology will help farmers in reducing yield gaps and will improve their knowledge, attitude and skill.
\end{abstract}

KEYWORDS: Frontline Demonstrations, Castor \& PCH 111 Hybrid

\section{INTRODUCTION}

Castor (Ricinuscommunis L.) belonging to the family Euphorbiaceae has $2 \mathrm{n}=20$ chromosome number. The crop is generally cross-pollinated (for more than 50 percent of the crop). Castor is native to India, Southeastern Mediterranean Basin and Eastern Africa but is a predominant cultivated crop in most tropical regions of the world. The crop is popular for cultivation in tropical, sub-tropical and temperate regions of the world. Approximately, 30 countries produce this crop for sale and marketing. Some of the notable countries to do so are India, Brazil, China, Russia, Thailand and Philippines. India is the leading cultivator in terms of area, production and productivity, which were estimated to be 10.4 lakh ha, 17.33 lakh tons and $1666.3 \mathrm{~kg} / \mathrm{ha}$, respectively during the year 2014 (FAOSTAT 2014).

In India, the main states growing castor are Gujarat, Rajasthan and Andhra Pradesh. In Telangana, cultivation of the crop was hugely popular in the southern districts of Mahaboobnagar, Rangareddy and Nalgonda, mainly because of their agro-climatic zone. In 2016, in India, the area under castor cultivation was about 11.10 lakh ha and production was about 17.75 lakh tons (Third Advance Estimates dated 9 September 2016). The yield was lower from 2014-15, when it was 18.70 lakh tons from an area of 10.89 lakh ha. The industrial applications of castor oil are numerous. It is used for manufacturing soaps, refined and perfumed hair oils, printing inks, 
varnishes, synthetic resins, carbon paper, lubricant, ointments, cosmetics and processed leather,

The productivity of castor may be improved by applying scientific and sustainable management production practices. This is usually achieved by adopting high-yielding varieties. Frontline demonstrations (FLDs) of crop cultivation mainly aim at advertising the newly released crop production technologies and its management practices directly in the farmer's fields. These are conducted in fields ranging from varying agro-climatic zones. Furthermore, frontline demonstrations help to examine the factors assisting in higher crop production, field constraints during production, as well as generating production data and farmer's feedback information.

\section{MATERIALS AND METHODS}

A total of 20 fields of farmers residing in Mahabubnagar district of south zone of Telangana state were selected for the experimental study. The field studies were conducted by the Krishi Vigyan Kendra, Palem to evaluate the production and economic benefits of castor ( $\mathrm{PCH} 111)$ production by applying scientific technology. The crop cultivated during the kharif season of 2012-13 and 2013-14 (two consecutive years) was selected for testing and analyses. The fields of the farmers were located in the village of Chenchugudem, Gudibanda and Chakalpalyy. The experimental study area was 8 ha. Each farmer contributed one acre for the frontline demonstrations. This study was conducted with the active participation of farmers from selected village. Prior to starting the frontline demonstrations, skill training was imparted to the selected farmers and group meetings organized. These training schedules helped the farmer to understand the different aspects of castor cultivation. To promote castor production using scientific technology, constrains in castor production were identified though participatory approach. Knowledge on improved varieties, seed treatment, maintenance of optimum plant stand and recommended fertilizer dose was imparted to the farmers and experimentally tested in their fields. The spacing between crops was $0.90 \mathrm{~m} \times 0.60 \mathrm{~m}$. Seeds were sown at the rate of $6 \mathrm{~kg} / \mathrm{ha}$. Extension gap, technology gap and technology index were calculated using the formulas suggested by Samui $e t$ al. (2000).

$$
\begin{aligned}
& \text { Extension gap }(\mathbf{q} / \mathbf{h a})=\text { Demonstration yield }\left(\mathrm{qha}^{-1}\right)-\text { yield of local check }\left(\mathrm{qha}^{-1}\right) \\
& \text { Technology gap }(\mathbf{q} / \mathbf{h a})=\text { Potential yield }\left(\mathrm{qha}^{-1}\right)-\text { Demonstration yield }\left(\mathrm{qha}^{-1}\right) \\
& \text { Technology index }(\%)=\text { Potential yield }\left(\mathrm{qha}^{-1}\right)-\text { Demonstration yield }\left(\mathrm{qha}^{-1}\right) / \text { Potential yield x100 }
\end{aligned}
$$

\section{RESULTS AND DISCUSSION}

\section{Constraints in Castor Production}

The various constraints experienced by the farmer during the field application of numerous castor cultivation methods were documented in this study. Preferential ranking of the scientific techniques faced by the respondent farmer helped identify the difficulties that need to be given priority during castor production. The ranking details are listed in Table 1. The lack of availability of high-yielding variety (HYV) (80.00\%) at low cost was considered the major inhibitory factor for successful crop production.

Apart from the non-availability of HYV, low technical knowledge, low or erratic rainfall especially mid-season drought, high labor cost and post-harvest management were identified as important factors influencing castor production. 
Among all the constraints, low soil fertility was the least concern.

Table 1: Ranking of the Cultivation Constraints by the Farmers

\begin{tabular}{|l|c|c|}
\hline \multicolumn{1}{|c|}{ Constraints } & Percentage & Rank \\
\hline Availability of suitable HYV & 80.00 & I \\
\hline Labour problem & 72.00 & III \\
\hline Low soil fertility & 35.00 & VII \\
\hline Marketing & 68.00 & V \\
\hline Low technical knowledge & 60.00 & VI \\
\hline Wild animals & 70.00 & IV \\
\hline $\begin{array}{l}\text { Vagaries of weather } \\
\text { (Delay onset of monsoon, Early withdrawal of monsoon) }\end{array}$ & 78.00 & II \\
\hline
\end{tabular}

Performance of FLD: The productivity yields of the hybrid (PCH 111) and local crop hybrid were compared. The details are listed in Table 2. For the experimental study period, the productivity of hybrid castor PCH 111 improved on applying production technologies; the productivity ranged from 14 to $24.2 \mathrm{q} / \mathrm{ha}$ (mean yield 20.23q/ha)for the cultivation year 2012 and from 16 to $23.9 \mathrm{q} / \mathrm{ha}$ (mean yield20.88 q/ha)for the cultivation year 2013.However, for the local hybrid, the productivity was only 16.53 and $17.07 \mathrm{q} / \mathrm{ha}$ mean yield for the cultivation years 2012 and 2013, respectively.

The difference in yield between the frontline demonstrations and potential yield of PCH 111 hybrid was noted. This helped to determine yield gaps, which helped to calculate the technology index. The technology gap displayed the gap difference between demonstration yield and potential yield ( $25 \mathrm{q} / \mathrm{ha})$. Technology index indicated the feasibility of the hybrid for cultivation. Technology index and feasibility were noted to be inversely related.

This study indicated a technology gap of $1.77 \mathrm{q} / \mathrm{ha}$. This highlights the urgent requirement to educate and train farmers to lessen the technology gap. This can be achieved by adopting improved agricultural production technologies. The concern by the farmer regarding their lack of technological skills displays their cooperation in this experimental study, which was the main reason for the encouraging results observed. The farmers were eager to adopt the skills taught. The technology gap could also be because of varying soil fertility and unpredictable weather conditions. Mukharji (2003) noted that the farming situation needs to be analyzed to identify the areas that should be focused on. Such an approach with specific intervention will enhance productivity in a systemic manner. A similar approach was suggested by Mitraet al. (2010) and Katareet al. (2011) as well.

The economic feasibility of improved technology over traditional farming systems was calculated based on the existing input and output costs. For castor cultivation, the cost of production using improved technology led to an increase from Rs. 18500 to 19170 ha $^{-1}$ for the hybrid variety PCH 111 in comparison to local hybrid varieties atRs17450 to18200 ha

${ }^{1}$. Frontline demonstration recorded a higher meannet return (Rs.52305and 53910/ha) with higher benefit cost ratio (3.82 and 3.81).

The yield gap between conventional practices and improved production technology was perceptibly higher. Frontline demonstrations yielded better productivity that the local hybrids. Therefore, it can be concluded that adoption of high yielding hybrid resulted in improved productivity. Consequently, this would help improve the economic situation of the farmers, as such practices would result in increased income. This in turn would help enhance the livelihood standards of the farming community. 


\section{CONCLUSIONS}

New crop varieties and technologies can be promoted with frontline demonstrations. These provide good platforms for advertising the benefits with proven results. Further, these platforms help to improve the knowledge, attitude and skills of farmers, which will help reduce the prevailing yield gaps.

Table 2

\begin{tabular}{|c|c|c|c|c|c|c|c|c|c|c|c|}
\hline Year & $\begin{array}{l}\text { Hybrid } \\
\text { (ha) }\end{array}$ & Area & $\begin{array}{l}\text { No. of } \\
\text { Demons } \\
\text { trations }\end{array}$ & $\begin{array}{c}\text { Potential } \\
\text { yield } q / h a\end{array}$ & $\begin{array}{l}\text { Max. } \\
\text { Yield } \\
\text { q/ha }\end{array}$ & $\begin{array}{l}\text { Mini. } \\
\text { Yield q/ha }\end{array}$ & $\begin{array}{l}\text { Avg. } \\
\text { Yield } \\
\text { q/ha }\end{array}$ & $\begin{array}{c}\text { Check } \\
\text { Avg Yield } \\
\text { q/ha }\end{array}$ & $\begin{array}{c}\text { Extens } \\
\text { ion } \\
\text { Gap } \\
(\mathrm{q} / \mathrm{ha}) \\
\end{array}$ & $\begin{array}{l}\text { Technol } \\
\text { ogy Gap } \\
\text { (q/ha) }\end{array}$ & $\begin{array}{c}\text { Techn } \\
\text { ology } \\
\text { Index } \\
(\%) \\
\end{array}$ \\
\hline 2012 & PCH 111 & 4 & 10 & 25 & 24.2 & 14 & 20.23 & 16.53 & 3.7 & 4.77 & 19.08 \\
\hline 2013 & PCH 111 & 4 & 10 & 25 & 23.9 & 16 & 20.88 & 17.07 & 3.81 & 4.12 & 16.48 \\
\hline Year & $\begin{array}{l}\text { Hybrid } \\
\text { (ha) }\end{array}$ & Area & No. & \multicolumn{2}{|c|}{$\begin{array}{l}\text { Total cost of } \\
\text { cultivation (Rs./ha) }\end{array}$} & $\begin{array}{l}\text { Gross } \\
\text { (Rs./ha) }\end{array}$ & return & \multicolumn{2}{|c|}{ Net return (Rs./ha) } & \multicolumn{2}{|c|}{$\begin{array}{l}\text { Benefit :cost } \\
\text { ratio }\end{array}$} \\
\hline & & & & $\begin{array}{l}\text { Improved } \\
\text { technology }\end{array}$ & Check & $\begin{array}{l}\text { Improved } \\
\text { technology }\end{array}$ & Check & $\begin{array}{l}\text { Improved } \\
\text { technology }\end{array}$ & Check & $\begin{array}{l}\text { Improve } \\
\text { d } \\
\text { technolo } \\
\text { gy }\end{array}$ & Check \\
\hline 2012 & PCH 111 & 4 & 10 & 18500 & $\begin{array}{c}1745 \\
0\end{array}$ & 70805 & 57855 & 52305 & 40405 & 3.82 & 3.31 \\
\hline 2013 & PCH 111 & 4 & 10 & 19170 & $\begin{array}{c}1820 \\
0\end{array}$ & 73080 & 59745 & 53910 & 41545 & 3.81 & 3.28 \\
\hline
\end{tabular}

\section{REFERENCES}

1. Mitra, Biplab and T. Samajdar (2010). Yield gap analysis of rapeseed-mustard through front line demonstration. Agric. Exten. Review, (April-June): 16-17.

2. Sreelakshmi, C.H., Sameer Kumar, C.V. and Shivani, D. (2012). Productivity enhancement of pigeon pea (CajanuscajanL.) through improved production technology. Madras Agricultural Journal, 99:248-250. 